\title{
Familiær kreftdebut kan påvirkes
}

\section{Kreft øker risikoen for kreft \\ hos avkommet, også når kreft- \\ diagnosen blir stilt i høy alder.}

Tidlig kreftdebut er vanligvis assosiert med en sterk arvelig komponent. En internasjonal forskningsgruppe har nå undersøkt arve-

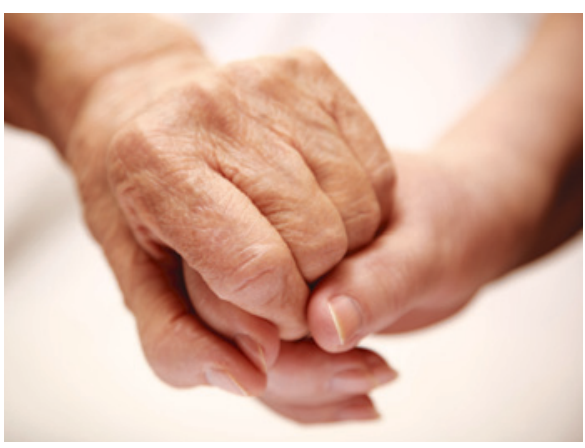

Illustrasjonsfoto Thinkstock lighet av kreft i en kreftdatabase som omfattet alle svensker født etter $1931 \mathrm{og}$ deres biologiske foreldre (1).

Basen omfattet over 12,2 millioner personer, hvorav flere enn 1,1 millioner tilfeller med første primærcancer. Den høyeste familiære risikoen ble observert hos avkom til foreldre som hadde fått kreftdiagnosen i ung alder. Risikoen var signifikant økt for kreft $\mathrm{i}$ tykk- og endetarm, lunge, bryst, prostata og blære samt for malignt melanom og plateepitelkarsinom i hud og for non-Hodgkins lymfom, selv når foreldrene fikk diagnosen i alderen 80-89 år.

- Studien er interessant og bekrefter oppfatningen om at noen er disponert for å få kreft, sier professor Steinar Tretli, avdelingsleder ved Kreftregisteret. Økt familiær kreftrisiko kan skyldes genetiske skader eller epigenetisk påvirkning i tillegg til ugunstige naturlige genvarianter. En familiær forhøyet risiko også når foreldrepersonen fikk kreftdiagnosen i høy alder, tyder på at miljø og livsstil påvirker sykdomsdebuten blant de disponerte. Studien antyder at familiære kreftformer ikke debuterer tidlig der familiemedlemmer fikk diagnosen sent. Men her kan det være seleksjonsproblemer som følge av at oppfølgingsperioden først starter i 1960 for begge kohorter.

- Størrelsen på risikoestimatene for kreft hos avkommet gir ikke grunnlag for store bekymringer hvis mor eller far får kreft på sine gamle dager, sier Tretli. Forfatterne av denne studien antyder at kreftforekomst i foreldregenerasjonen kan motivere avkommet til å gjøre gunstige endringer i livsstil, men studien gir ikke grunnlag for å si noe om forventet effekt av slike endringer, sier Tretli.

\section{Trine B. Haugen}

trine.b.haugen@hioa.no

Tidsskriftet

\section{Litteratur}

1. Kharazmi E, Fallah M, Sundquist K et al. Familial risk of early and late onset cancer: nationwide prospective cohort study. BMJ 2012; 345: e8076.

\section{Helsekontroll gir ingen helsegevinst}

\section{Generelle helsekontroller fører ikke til redusert sykelighet eller dødelighet for dem som blir kontrollert, ifølge ny metaanalyse.}

Generelle helsekontroller for friske mennesker er i noen land en vanlig del av helsevesenets oppgaver, selv om nytten av slike tiltak ikke er godt dokumentert. Forskere har nå gjort en systematisk gjennomgang og metaanalyse for å tallfeste fordeler og ulemper ved helsekontroller (1).

En generell helsekontroll ble definert som en screening av den generelle befolkningen for mer enn én sykdom eller risikofaktor i mer enn ett organsystem. Til sammen 14 randomiserte forsøk som sammenliknet helsekontroll med ingen helsekontroll hos voksne opptil 65 år, ble inkludert.

I ni av studiene oppga man effekt i totaldødelighet, med en risikorate for død hos kontrollerte versus ikke-kontrollerte i oppfølgingsperioden på 0,99 (95\% KI 0,95-1,03). Åtte studier rapporterte hjerte- og kardødelighet, med risikorate $1,03(0,91-1,17)$, og åtte studier rapporterte kreftrelatert dødelighet, med risikorate $1,01(0,92-1,12)$. I studiene rapporterte man ikke mål for sykelighet på en enhetlig måte. Metaanalyser kunne derfor ikke gjennomføres, men ved en kvalitativ oppsummering av resultatene kom forskerne til at helsekontroller heller ikke ga noen positive effekter på sykelighet, sykehusinnleggelser, bekymring, sykefravær eller uførhet.

- Det er ingen nyhet at generelle helsekontroller gir liten effekt til en høy pris, sier seniorforsker Signe Flottorp ved Kunnskapssenteret. Denne gjennomgangen viser på en solid måte at vi mangler dokumentasjon for slike kontroller. Riktignok var det ganske gamle studier som ble vurdert, men selv ved dagens helsekontroller vil jeg tro det er vanskelig å påvise mer enn en marginal effekt, sier Flottorp. For pasienter er det langt mer fornuftig å være $\mathrm{i}$ et kontinuerlig lege-pasient-forhold hos fastlegen enn å gjennomgå generelle helsekontroller, mener hun.

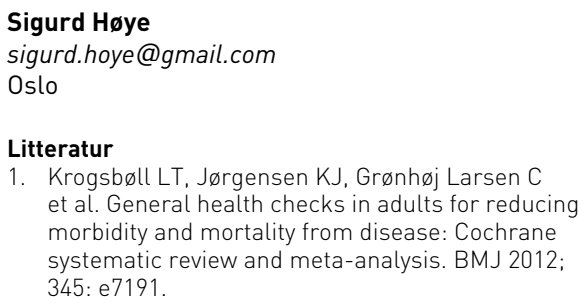

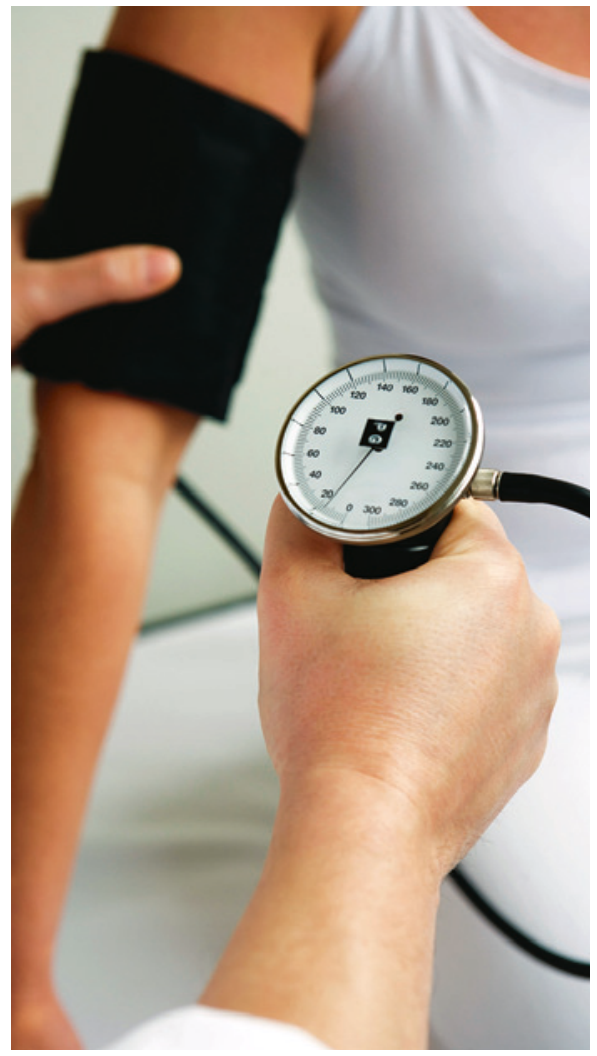

Illustrasjonsfoto Thinkstock 